\title{
Photoinduced $E$ to $Z$ isomerization of tetraphenylethylene derivatives within organometallic supramolecular assemblies
}

\author{
Xiao-Xu Liu ${ }^{1 \dagger}$, Yang $\mathrm{Li}^{1 \dagger}$, Xin $\mathrm{Li}^{1}, \mathrm{~F}$. Ekkehardt $\mathrm{Hahn}^{1,2^{*}}$ \& Ying-Feng Han ${ }^{1 *}$ \\ ${ }^{1}$ College of Chemistry and Materials Science, Northwest University, Xi'an 710127, China; \\ ${ }^{2}$ Institut für Anorganicshe und Analytische Chemie Westfälische Wilhelms-Universität Münster Corrensstrasse 30, 48149 Münster, Germany
}

Received April 29, 2021; accepted June 4, 2021; published online August 19, 2021

\begin{abstract}
Isolation of $E$-1,2-bis(4-bromophenyl)-1,2-diphenyl-ethylene from the $E / Z$ isomer mixture obtained by a McMurry coupling reaction and reaction of this isomer with imidazole followed by $N$-alkylation with $n \mathrm{BuBr}$ and anion exchange yielded the bisimidazolium tetraphenylethylene (TPE) derivative $\mathrm{H}_{2}-E-\mathbf{1}\left(\mathrm{PF}_{6}\right)_{2}$. The reaction of $\mathrm{H}_{2}-E-\mathbf{1}\left(\mathrm{PF}_{6}\right)_{2}$ with $\mathrm{Ag}_{2} \mathrm{O}$ yielded the dinuclear metallarectangle $\left[\mathrm{Ag}_{2}(E-1)_{2}\right]\left(\mathrm{PF}_{6}\right)_{2}$ where the two bis-NHC donors $E$-1 bridge two silver atoms. Irradiation of $\left[\mathrm{Ag}_{2}(E-\right.$ 1) $\left.)_{2}\right]\left(\mathrm{PF}_{6}\right)_{2}$ leads to $E / Z$ isomerization of the di-NHC ligand and formation of $Z-\mathbf{1}$ in the mononuclear complex $[\mathrm{Ag}(Z-\mathbf{1})] \mathrm{PF}_{6}$. Demetallation of the di-NHC ligand with $\mathrm{NH}_{4} \mathrm{Cl} / \mathrm{NH}_{4} \mathrm{PF}_{6}$ yielded bisimidazolium salt $\mathrm{H}_{2}-Z-1\left(\mathrm{PF}_{6}\right)_{2}$. The unique isomerization of the $E$-TPE derivative into its $Z$-isomer via metal complex formation/irradiation/demetallation cannot be achieved by irradiation of the individual imidazolium salt. The emissive properties of the TPE complexes $\left[\mathrm{Ag}_{2}(E-1){ }_{2}\right]\left(\mathrm{PF}_{6}\right)_{2}$ and $[\mathrm{Ag}(Z-1)] \mathrm{PF}_{6}$ have been investigated.
\end{abstract}

\section{N-heterocyclic carbene, tetraphenylethylene, photochemical isomerization, fluorescence, EZI process}

Citation: Liu XX, Li Y, Li X, Hahn FE, Han YF. Photoinduced $E$ to $Z$ isomerization of tetraphenylethylene derivatives within organometallic supramolecular assemblies. Sci China Chem, 2021, 64: 1709-1715, https://doi.org/10.1007/s11426-021-1041-8

\section{Introduction}

Tetraphenylethylene (TPE) and its derivatives have become the most extensively studied aggregation-induced-emission (AIE) luminogens. They have found multiple applications since the introduction of the concept of AIE by Tang and coworkers $[1,2]$. Many TPE derivatives exhibit strong fluorescence in the solid state or as colloidal aggregates due to restricted intramolecular rotation (RIR), whereas the observation of almost no or only weak fluorescence in dilute solution is generally ascribed to the dynamic intramolecular rotation of the phenyl groups against the ethylene stator [35]. The radiationless relaxation of excitons by the RIR mechanism has been established by a wealth of theoretical and experimental research. In addition, TPE can also undergo

$\dagger$ These authors contributed equally to this work.

*Corresponding authors (email: yfhan@nwu.edu.cn; fehahn@uni-muenster.de.)
$E / Z$ isomerization (EZI) under light irradiation or by heating (Scheme 1). Whether or not the EZI process leads to an emission reduction for TPE derivatives is still subject of discussion [6-9].

The photoinduced isomerization is difficult to observe for symmetrical TPE derivatives. Therefore, the EZI process has been studied with unsymmetrically disubstituted TPE derivatives [6-17]. Apart from being ideal candidates for the study of the EZI process, pure $E$ - and $Z$-isomers of disubstituted TPE and the investigation of their properties has recently attracted interest based on the differences in their optical properties, host-guest chemistry and related features [18-28]. Disubstituted TPE derivatives are conventionally synthesized by the McMurry coupling of unsymmetrically sybstituted ketones. This protocol normally yields a mixture of $E$ - and $Z$-isomers (Scheme 1) [29-32]. Separation of these isomers by column chromatography proved difficult owing 

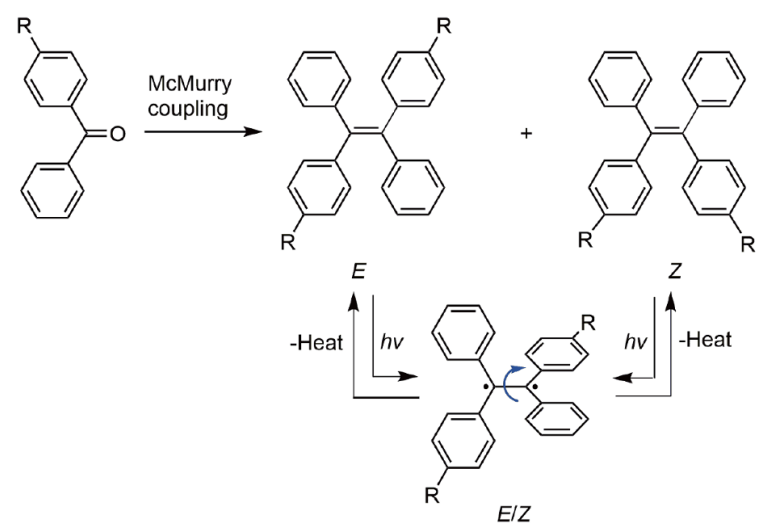

Scheme 1 Synthesis of $E / Z$-TPE derivatives through the McMurry coupling reaction and $E / Z$ isomerisation in solution (color online).

to the similarity in the properties of the isomers [29-33]. Increasing the difference in polarity of the isomers is the usual but not the only method to achieve separation of the isomers $[9,34]$. The isomerization of disubstituted TPE derivatives under ultraviolet (UV) irradiation or by thermal treatment constitutes a promising method to obtain pure $E$ and $Z$-isomers. However, the quantitative conversion of one isomer into the other one has not been realized so far $[8,31,34]$, although the isomerization rate of the $E$ - to the $Z$ isomer is lower than the reverse isomerization of the $Z$ - to $E$ isomer due to the higher stability of the $E$-isomer (Scheme 1) $[30,31,35]$. Thus, the acquisition of pure $E$ - and $Z$-isomers of disubstituted TPE derivatives remains a challenge both in terms of synthesis and separation technology.

The chemistry of metal complexes bearing N-heterocyclic carbene (NHC) ligands has rapidly evolved over the last years with interesting applications ranging across a diverse set of fields. Recently a number of studies have focused on metallosupramolecular assemblies obtained from poly-NHC ligands and their postsynthetic modifications [36-44]. The synthesis of poly-NHC- $\mathrm{Ag}^{\mathrm{I}}$ assemblies from $\mathrm{Ag}_{2} \mathrm{O}$ and polyNHC precursors has been most extensively investigated. This protocol benefits not only from the simplicity of the synthetic procedure but also from the lability of $\mathrm{Ag}^{\mathrm{I}}-\mathrm{C}_{\mathrm{NHC}}$ bond [39], allowing the formation of the thermodynamically most stable reaction product and the transmetallation of the poly-NHC from silver to other metals [45-48].

We have demonstrated turn-on fluorescence by rigidification as an alternative to AIE in dinuclear complexes of tetra-NHC-substituted TPE of type A (Scheme 2, top) $[49,50]$. In complexes of type A both the RIR and the EZI mechanism for radiationless relaxation are disabled through the formation of two metallacycles involving Z-NHC donors. Inspired by the stability of the $Z$-arrangement of the NHC donors in $\mathbf{A}$ and the lability of the $\mathrm{Ag}-\mathrm{C}_{\mathrm{NHC}}$ bond in general, we assumed that dinuclear silver complexes of di-NHC substituted TPE derivatives in $E$-configuration might undergo the isomerization to the $Z$-complexes upon UV irra-
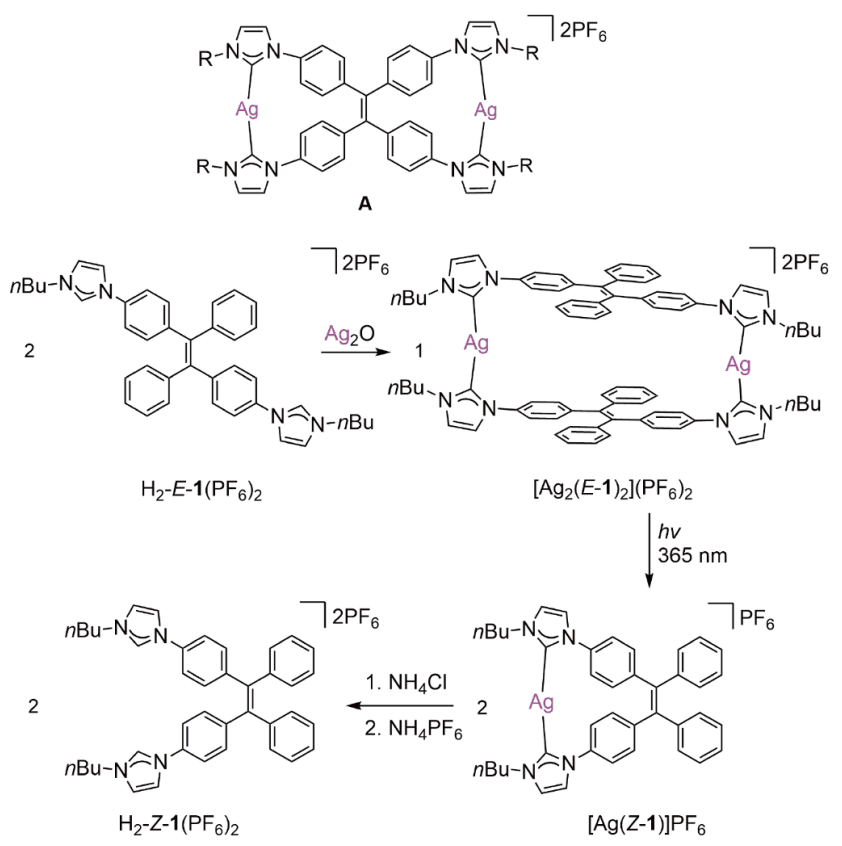

Scheme 2 Synthesis of $\left[\mathrm{Ag}_{2}(E-\mathbf{1})_{2}\right]\left(\mathrm{PF}_{6}\right)_{2}$ from $\mathrm{H}_{2}-E-\mathbf{1}\left(\mathrm{PF}_{6}\right)_{2}$, the irradiation induced transformation to $[\mathrm{Ag}(Z-1)] \mathrm{PF}_{6}$ and demetallation of $[\mathrm{Ag}$ $(Z-1)] \mathrm{PF}_{6}$ to give $\mathrm{H}_{2}-Z-1\left(\mathrm{PF}_{6}\right)_{2}$ (color online).

diation via the EZI process.

Here we describe the molecular rectangle $\left[\mathrm{Ag}_{2}(E-\mathbf{1})_{2}\right]-$ $\left(\mathrm{PF}_{6}\right)_{2}$ obtained from the bisimidazolium TPE salt $\mathrm{H}_{2}-E$ $\mathbf{1}\left(\mathrm{PF}_{6}\right)_{2}$ and $\mathrm{Ag}_{2} \mathrm{O}$ (Scheme 2, bottom). Upon irradiation, the dinuclear complex $\left[\mathrm{Ag}_{2}(E-\mathbf{1})_{2}\right]\left(\mathrm{PF}_{6}\right)_{2}$ quantitatively converts into the mononuclear complex $[\operatorname{Ag}(Z-1)] \mathrm{PF}_{6}$. Demetallation of $[\mathrm{Ag}(Z-1)] \mathrm{PF}_{6}$ yielded salt $\mathrm{H}_{2}-Z-1\left(\mathrm{PF}_{6}\right)_{2}$ which, to our knowledge, constitutes the first controlled quantitative transformation of $E$ - to Z-TPE derivatives through an organometallic supramolecular assembly. In addition, the $\mathrm{Ag}^{\mathrm{I}}$ complexes $\left[\mathrm{Ag}_{2}(E-\mathbf{1})_{2}\right]\left(\mathrm{PF}_{6}\right)_{2}$ and $[\mathrm{Ag}(Z-\mathbf{1})] \mathrm{PF}_{6}$ exhibit AIE induced luminescence in $\mathrm{CH}_{3} \mathrm{CN} / \mathrm{H}_{2} \mathrm{O}$ solvent mixtures.

\section{Results and discussion}

The bisimidazolium salt $\mathrm{H}_{2}-E-\mathbf{1}\left(\mathrm{PF}_{6}\right)_{2}$ was obtained by the copper-catalyzed coupling reaction of E-1,2-bis(4-bromophenyl)-1,2-diphenylethene and imidazole. The resulting bis(4-imidazolphenyl)-1,2-diphenylethene was obtained as a mixture of $E$ and $Z$ isomers and the latter one was removed by multiple crystallization steps [51]. A subsequent double $N$-alkylation with $n$-butylbromide gave the dibromide salt which was converted into the hexafluorophosphate salt $\mathrm{H}_{2}-$ $E-1\left(\mathrm{PF}_{6}\right)_{2}$ by reaction with $\mathrm{NH}_{4} \mathrm{PF}_{6}$ (Scheme $\mathrm{S} 1$, for experimental details see the Supporting Information online).

The bisimidazolium salt $\mathrm{H}_{2}-E-\mathbf{1}\left(\mathrm{PF}_{6}\right)_{2}$ was fully characterized by nuclear magnetic resonance (NMR) spectroscopy and high-resolution electrospray ionization (HR ESI) mass spectrometry (see the Supporting Information online). 
In addition, the molecular structure of $\mathrm{H}_{2}-E-\mathbf{1}\left(\mathrm{PF}_{6}\right)_{2}$ was established by an X-ray diffraction study (Figure S1, Supporting Information online).

Reaction of $\mathrm{H}_{2}-E-\mathbf{1}\left(\mathrm{PF}_{6}\right)_{2}$ with an excess of $\mathrm{Ag}_{2} \mathrm{O}$ in dry acetonitrile at $55^{\circ} \mathrm{C}$ for $24 \mathrm{~h}$ under exclusion of light yielded complex $\left[\mathrm{Ag}_{2}(E-1)_{2}\right]\left(\mathrm{PF}_{6}\right)_{2}$ in $70 \%$ yield (Scheme 2 and Scheme S2, see the Supporting Information online). The formation of the organometallic rectangle was confirmed by NMR and mass spectrometry. The ${ }^{1} \mathrm{H}$ NMR spectrum of $\left[\mathrm{Ag}_{2}(E-\mathbf{1})_{2}\right]\left(\mathrm{PF}_{6}\right)_{2}$ (Figure 1b) did not feature the resonance for the imidazolium $\mathrm{H} 2$ proton anymore, which was observed for the bisimidazolium salt at $\delta=8.79 \mathrm{ppm}$ (Figure 1a). The ${ }^{13} \mathrm{C}\left\{{ }^{1} \mathrm{H}\right\}$ spectrum of $\left[\mathrm{Ag}_{2}(E-1)_{2}\right]\left(\mathrm{PF}_{6}\right)_{2}$ featured the resonance for the $\mathrm{C}_{\mathrm{NHC}}$ carbon atoms at $\delta=181.6 \mathrm{ppm}$ (by ${ }^{1} \mathrm{H}-{ }^{13} \mathrm{C}$ heteronuclear multiple bond correlation spectroscopy in $\mathrm{CD}_{3} \mathrm{CN}$, Figure $\mathrm{S} 12$ ). The base peak in the HR ESI mass spectrum (positive ions) was detected at $m / z=1513.4960$ (calcd for $\left.\left[\left[\mathrm{Ag}_{2}(E-1)_{2}\right] \mathrm{PF}_{6}\right]^{+}=1513.4249\right)$ (Figure 1c).

The absorption and emission spectra of $\mathrm{H}_{2}-E-\mathbf{1}\left(\mathrm{PF}_{6}\right)_{2}$ and $\left[\mathrm{Ag}_{2}(E-1)_{2}\right]\left(\mathrm{PF}_{6}\right)_{2}$ are depicted in Figure 2. The bisimidazolium salt $\mathrm{H}_{2}-E-\mathbf{1}\left(\mathrm{PF}_{6}\right)_{2}$ and the dinuclear complex $\left[\mathrm{Ag}_{2}(E-\right.$ 1) $\left.)_{2}\right]\left(\mathrm{PF}_{6}\right)_{2}$ exhibit essentially identical absorption spectra (Figure 2a) except for the slightly enhanced vibration structure observed for $\left[\operatorname{Ag}_{2}(E-1)_{2}\right]\left(\mathrm{PF}_{6}\right)_{2}$.

The emission spectra (Figure 2b) showed the expected weak emission for $\mathrm{H}_{2}-E-\mathbf{1}\left(\mathrm{PF}_{6}\right)_{2}$ due to nonradiative decay enabled by rotation of the TPE benzene rings. After complex formation to give $\left[\mathrm{Ag}_{2}(E-\mathbf{1})_{2}\right]\left(\mathrm{PF}_{6}\right)_{2}$, partial rigidification induced fluorescence enhancement [11] with a concurrent red-shift of the emission from $\lambda=385 \mathrm{~nm}$ (for $\mathrm{H}_{2}-E-\mathbf{1}_{\left.\left(\mathrm{PF}_{6}\right)_{2}\right)}$ to $\lambda=492 \mathrm{~nm}$ for $\left[\mathrm{Ag}_{2}(E-\mathbf{1})_{2}\right]\left(\mathrm{PF}_{6}\right)_{2}$.

Based on the observation of the UV radiation induced EZI process in TPE derivatives (Scheme 1), we became interested in extending this isomerization to complexes obtained from suitably disubstituted TPE derivatives. Isomerization of the di-NHC ligand $E$-1 in the dinuclear complex $\left.\left[\operatorname{Ag}_{2}(E-1)_{2}\right)\right]-$ $\left(\mathrm{PF}_{6}\right)_{2}$ would lead to ligand $Z-1$, which due to steric reasons will form a mononuclear dicarbene chelate complex $[\operatorname{Ag}(Z-$ 1) $] \mathrm{PF}_{6}$ similarly to the previously described tetra-NHC substituted TPE derivatives in complex A (Scheme 2) [49]. The freely less stable $Z$-TPE derivative is then stabilized in the chelate complex. Removal of the TPE derivative from $[\mathrm{Ag}(Z-\mathbf{1})] \mathrm{PF}_{6}$ yields $\mathrm{H}_{2}-Z-\mathbf{1}\left(\mathrm{PF}_{6}\right)_{2}$ (Scheme 2) and would then result in the selective transformation of the more stable $E$ - into the less stable $Z$-derivative via a complex formation/ isomerization reaction sequence.

Irradiation of complex $\left[\mathrm{Ag}_{2}(E-\mathbf{1})_{2}\right]\left(\mathrm{PF}_{6}\right)_{2}$ in acetonitrile with a Philips mercury high-pressure lamp $(\lambda=365 \mathrm{~nm})$ at ambient temperature yielded indeed the mononuclear chelate complex $\left[\mathrm{Ag}(Z-1) \mathrm{PF}_{6}\right.$. After irradiating of $\left[\mathrm{Ag}_{2}(E-\mathbf{1})_{2}\right]\left(\mathrm{PF}_{6}\right)_{2}$ for $5 \mathrm{~min}$, a new set of ${ }^{1} \mathrm{H} \mathrm{NMR}$ signals for $[\mathrm{Ag}(Z-1)] \mathrm{PF}_{6}$ emerged at $\delta=7.46$ (H5), $7.37(\mathrm{H} 4), 7.20-7.26(\mathrm{H} 12-\mathrm{H} 14)$, 7.17 (H7), 6.97 (H8), 4.25 (H15) 1.94 (H16), 1.42 (H17) and
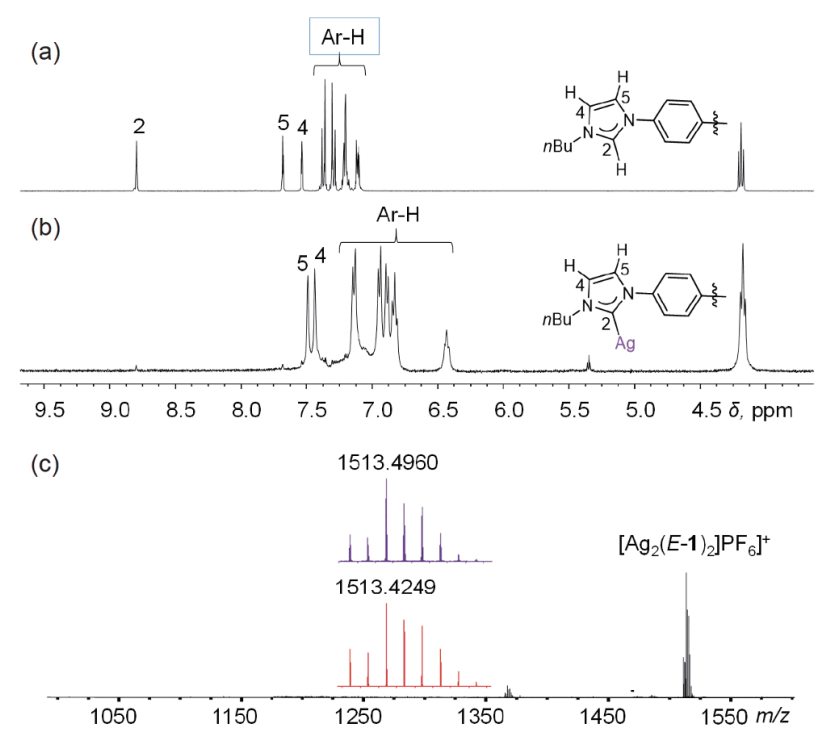

Figure 1 Sections of the ${ }^{1} \mathrm{H}$ NMR spectra of (a) $\mathrm{H}_{2}-E-1\left(\mathrm{PF}_{6}\right)_{2}$ and (b) $\left[\mathrm{Ag}_{2}(E-1)_{2}\right]\left(\mathrm{PF}_{6}\right)_{2} ;$ (c) ESI mass spectrum of $\left[\mathrm{Ag}_{2}(E-1){ }_{2}\right]\left(\mathrm{PF}_{6}\right)_{2}$ (inset: observed, top; calculated, bottom, isotope distribution) (color online).
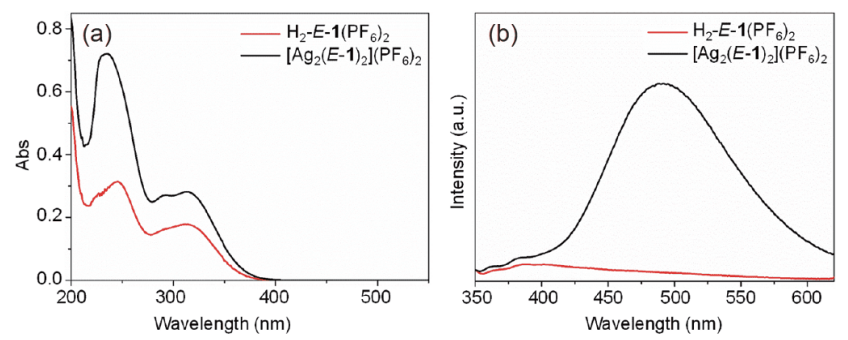

Figure 2 (a) UV-vis absorption and (b) fluorescence emission spectra of $\mathrm{H}_{2}-E-1\left(\mathrm{PF}_{6}\right)_{2}$ and $\left[\mathrm{Ag}_{2}(E-1){ }_{2}\right]\left(\mathrm{PF}_{6}\right)_{2}\left(\right.$ in $\left.\mathrm{CH}_{3} \mathrm{CN}, c=10^{-5} \mathrm{M}, \lambda_{\mathrm{ex}}=314 \mathrm{~nm}\right)$ (color online).

0.99 (H18) ppm, while the intensity of the signals for the starting complex $\left[\mathrm{Ag}_{2}(E-\mathbf{1})_{2}\right]\left(\mathrm{PF}_{6}\right)_{2}$ diminishes (Figure 3). The fraction of $[\operatorname{Ag}(Z-1)] \mathrm{PF}_{6}$ in the irradiated mixture rapidly increased to $68 \%$ over the first $20 \mathrm{~min}$. Subsequently, the rate of EZI slowed down and after $55 \mathrm{~min}$, no resonance for $\left.\mathrm{Ag}_{2}(E-\mathbf{1})_{2}\right]\left(\mathrm{PF}_{6}\right)_{2}$ were detected anymore confirming complete transformation to $[\mathrm{Ag}(Z-1)] \mathrm{PF}_{6}$. The isomerization to give $[\mathrm{Ag}(Z-1)] \mathrm{PF}_{6}$ was also supported by mass spectroscopy, showing only one intense peak at $\mathrm{m} / \mathrm{z}=683.2305$ (calcd for $[\operatorname{Ag}(Z-1)]^{+}=683.2297$ ) with the correct isotope distribution (Figure S20) for the compound obtained after irradiation of $\left[\mathrm{Ag}_{2}(E-\mathbf{1})_{2}\right]\left(\mathrm{PF}_{6}\right)_{2}$.

Finally, the conversion of dinuclear $\left[\mathrm{Ag}_{2}(E-1)_{2}\right]\left(\mathrm{PF}_{6}\right)_{2}$ to mononuclear $[\operatorname{Ag}(Z-1)] \mathrm{PF}_{6}$ can be monitored by the concurrent changes in the fluorescence emission spectra of the two complexes (Figure 4). With irradiation time, the intensity of the emission observed for $\left[\operatorname{Ag}_{2}(E-\mathbf{1})_{2}\right]\left(\mathrm{PF}_{6}\right)_{2}$ at $\lambda=$ $492 \mathrm{~nm}$ gradually decreases and a new red-shifted peak emerges at $\lambda=512 \mathrm{~nm}$ for complex $[\mathrm{Ag}(Z-1)] \mathrm{PF}_{6}$. The conversion rate monitored by fluorescence emission spec- 

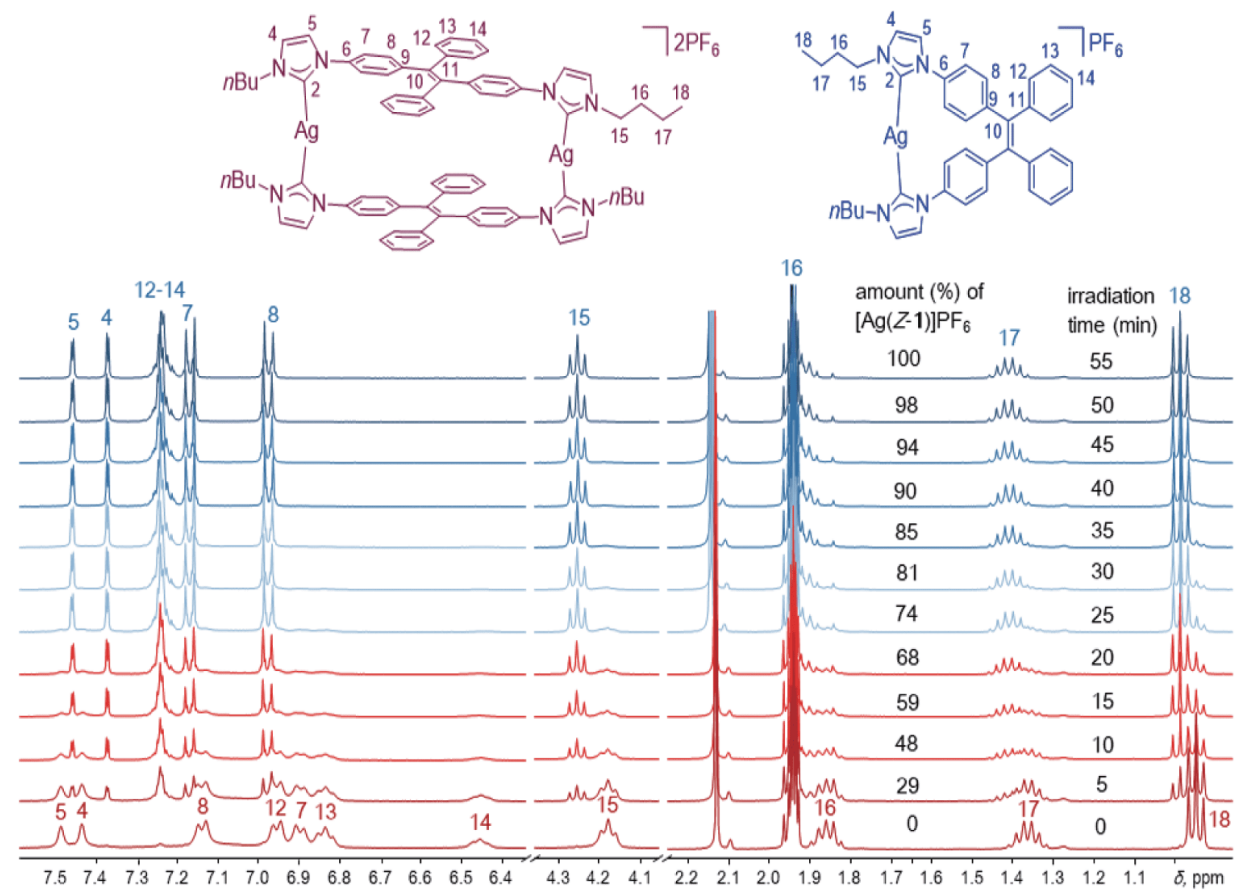

Figure $3 \quad{ }^{1} \mathrm{H}$ NMR spectra of $\left[\mathrm{Ag}_{2}(E-1)_{2}\right]\left(\mathrm{PF}_{6}\right)_{2}$ before (bottom) and during irradiation to give $[\mathrm{Ag}(Z-1)] \mathrm{PF}_{6}$ (top) (color online).

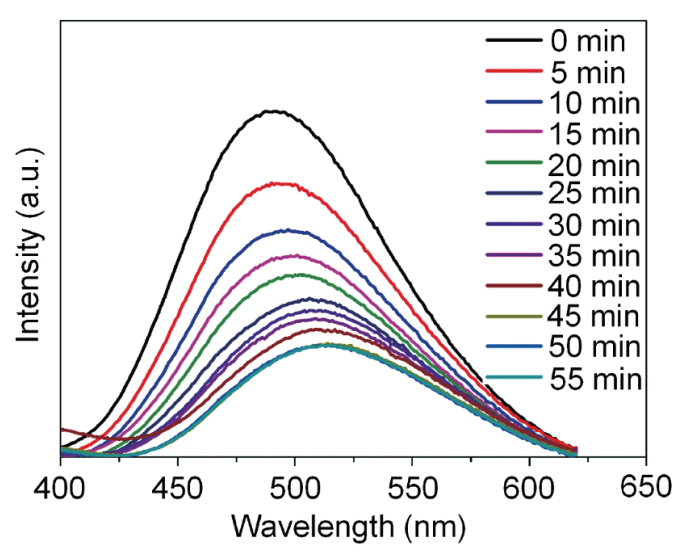

Figure 4 Fluorescence emission spectra of $\left[\mathrm{Ag}_{2}(E-\mathbf{1})_{2}\right]\left(\mathrm{PF}_{6}\right)_{2}$ after different irradiation times (in $\mathrm{CH}_{3} \mathrm{CN}, c=10^{-5} \mathrm{M}, \lambda_{\mathrm{ex}}=314 \mathrm{~nm}$ ) (color online).

troscopy is essentially identical to the rate observed by ${ }^{1} \mathrm{H}$ NMR spectroscopy (Figure 3). The fluorescence lifetimes of complexes $\left[\mathrm{Ag}_{2}(E-1)_{2}\right]\left(\mathrm{PF}_{6}\right)_{2}$ and $[\mathrm{Ag}(Z-1)] \mathrm{PF}_{6}$ both in solution and the solid state have been determined. All values fall in the nanosecond range, suggesting fluorescence deactivation from the lowest singlet states (Table S3, Supporting Information online).

Single crystal of $[\operatorname{Ag}(Z-1)] \mathrm{PF}_{6}$ suitable for an X-ray diffraction analysis was grown by slow diffusion of diethyl ether into a concentrated acetonitrile solution of the compound at ambient temperature. The X-ray diffraction study (Figure 5) confirmed the composition and geometry of [Ag$(Z-1)] \mathrm{PF}_{6}$ as concluded from NMR and mass spectrometric

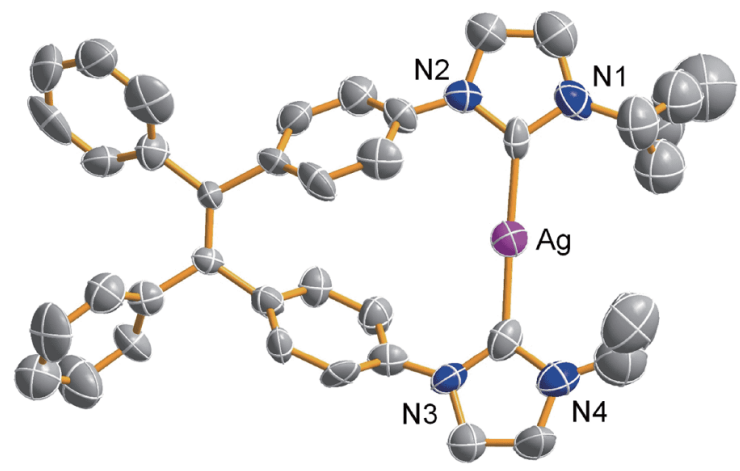

Figure 5 Molecular structure of cation $[\operatorname{Ag}(Z-1)]^{+}$in $[\operatorname{Ag}(Z-1)] \mathrm{PF}_{6}$ (color online).

analysis. The two imidazolylidene donors attached to the TPE core are located on the same side of the olefin bond. They are linked by coordination to one silver atom to form a planar chelate ring. The $\mathrm{C}-\mathrm{Ag}$ bond lengths of 2.084(7) and 2.092(7) $\AA$ and the $\mathrm{C}-\mathrm{Ag}-\mathrm{C}$ angle of $177.4(4)^{\circ}$ fall in the typical range for silver (I) di-NHC complexes [10-12].

The $Z$-TPE bridged dicarbene ligand in $[\operatorname{Ag}(Z-1)] \mathrm{PF}_{6}$ was liberated as the bisimidazolium salt $\mathrm{H}_{2}-Z-\mathbf{1}\left(\mathrm{PF}_{6}\right)_{2}$ by reaction of the complex with $\mathrm{NH}_{4} \mathrm{Cl}$ in a methanol and acetonitrile solvent mixture followed by anion exchange with $\mathrm{NH}_{4} \mathrm{PF}_{6}$ in methanol (Scheme 2). Compound $\mathrm{H}_{2}-\mathrm{Z}-\mathbf{1}\left(\mathrm{PF}_{6}\right)_{2}$ was characterized by multinuclear NMR spectroscopy and mass spectrometry (Figures S21-S23). The ${ }^{1} \mathrm{H}$ NMR spectrum exhibits the resonance for the imidazolium $\mathrm{N}-\mathrm{CH}-\mathrm{N}$ proton at $\delta=8.81 \mathrm{ppm}$. The base peak in the mass spectrum was 
recorded at $m / z=723.3044$ (calcd for $\left[\mathrm{H}_{2}-Z-1\right]^{+} 723.3046$ ). Inspired by the irradiation induced conversion of $\left[\operatorname{Ag}_{2}(E-\right.$ 1) $\left.)_{2}\right]\left(\mathrm{PF}_{6}\right)_{2}$ to $[\mathrm{Ag}(Z-1)] \mathrm{PF}_{6}$, an equimolar mixture of the isomeric imidazolium salts $\mathrm{H}_{2}-E-\mathbf{1}\left(\mathrm{PF}_{6}\right)_{2}$ and $\mathrm{H}_{2}-Z-\mathbf{1}\left(\mathrm{PF}_{6}\right)_{2}$ was prepared from a 1:1 isomer mixture of $E / Z-1,2-$ bis(4bromophenyl)-1,2-diphenylethene and imidazole followed by $N$-alkylation (Scheme 3, for experimental details see the Supporting Information online). Irradiation of this mixture of bisimidazolium salts does not yield only one, the slightly more stable $E$-isomer (Figure S30). Instead, the composition of the mixture of isomeric salts does not change noticeable upon irradiation. In addition, irradiation of the single isomer $\mathrm{H}_{2}-E-\mathbf{1}\left(\mathrm{PF}_{6}\right)_{2}$ leads to partial isomerization and formation of a mixture of isomeric salts $\mathrm{H}_{2}-E / Z-\mathbf{1}\left(\mathrm{PF}_{6}\right)_{2}$ as shown by ${ }^{1} \mathrm{H}$ NMR spectroscopy (Figure S30).

Contrary to these observations, reaction of an equimolar mixture of the isomeric bisimidazolium salts $\mathrm{H}_{2}-E-\mathbf{1}\left(\mathrm{PF}_{6}\right)_{2}$ and $\mathrm{H}_{2}-\mathrm{Z}-\mathbf{1}\left(\mathrm{PF}_{6}\right)_{2}$ with $\mathrm{Ag}_{2} \mathrm{O}$ followed by irradiation of the formed complexes mixture of $\left[\mathrm{Ag}_{2}(E-\mathbf{1})_{2}\right]\left(\mathrm{PF}_{6}\right)_{2}$ and $[\mathrm{Ag}(Z-$ 1) $\mathrm{PF}_{6}$ with a mercury high-pressure lamp $(\lambda=365 \mathrm{~nm})$ for 35 min yielded exclusively complex $[\operatorname{Ag}(Z-1)] \mathrm{PF}_{6}$ (Scheme $3)$. This selectivity must be attributed to the stabilization of the $Z$-dicarbene ligand in complex $[\operatorname{Ag}(Z-1)] \mathrm{PF}_{6}$ which thus becomes the only reaction product upon irradiation of the complex mixture. Such stabilization cannot occur in the bisimidazolium salts.

The transformation of the complex mixture $\left[\mathrm{Ag}_{2}(E-\mathbf{1})_{2}\right]-$ $\left(\mathrm{PF}_{6}\right)_{2} /[\mathrm{Ag}(Z-1)] \mathrm{PF}_{6}$ into pure $[\mathrm{Ag}(Z-1)] \mathrm{PF}_{6}$ was monitored by ${ }^{1} \mathrm{H}$ NMR spectroscopy. The ${ }^{1} \mathrm{H}$ NMR spectrum of the complex mixture (Figure 6, top) shows resonances for both $\left[\mathrm{Ag}_{2}(E-1)_{2}\right]\left(\mathrm{PF}_{6}\right)_{2}$ and $\left[\mathrm{Ag}(Z-1) \mathrm{PF}_{6}\right.$. The spectrum after 35 min of irradiation only exhibits resonances for mononuclear $\left[\mathrm{Ag}(Z-1) \mathrm{PF}_{6}\right.$.

Given the rigidification-induced desirable emission properties of dinculear complexes of type A (Scheme 2) [12], we became interested in the emission properties of the less rigid complexes $\left[\mathrm{Ag}_{2}(E-\mathbf{1})_{2}\right]\left(\mathrm{PF}_{6}\right)_{2}$ and $[\mathrm{Ag}(Z-\mathbf{1})] \mathrm{PF}_{6}$. The emission spectra of the complexes have been recorded in $\mathrm{CH}_{3} \mathrm{CN} /$ $\mathrm{H}_{2} \mathrm{O}$ solution with varying water fractions. Apparently due to intramolecular phenyl rotation, the emission is weak for $\left[\mathrm{Ag}_{2}(E-1)_{2}\right]\left(\mathrm{PF}_{6}\right)_{2}$ in acetonitrile and does not change significantly as long as the water content is less than $60 \%$. A sudden increase in emission intensity due to agglomeration accompanied by a blue shift of the emission maximum from 492 to $443 \mathrm{~nm}$ was observed when the water content was increased to $70 \%$ (Figure $7 \mathrm{a}$ ). When the water content was further increased to $90 \%$, the emission intensity increased approximately the 19 fold magnitude relative to the emission intensity in pure $\mathrm{CH}_{3} \mathrm{CN}$ solution (Figure 7b) and the emission colour changed from invisible green to bright blue visible to the naked eye. The fluorescence quantum yield $\left(\Phi_{\mathrm{F}}\right)$ reached $47 \%$ for the aggregated state in the $\mathrm{CH}_{3} \mathrm{CN} /$ $\mathrm{H}_{2} \mathrm{O}$ solvent mixture (with $90 \%$ water content) from $\Phi_{\mathrm{F}}=2 \%$
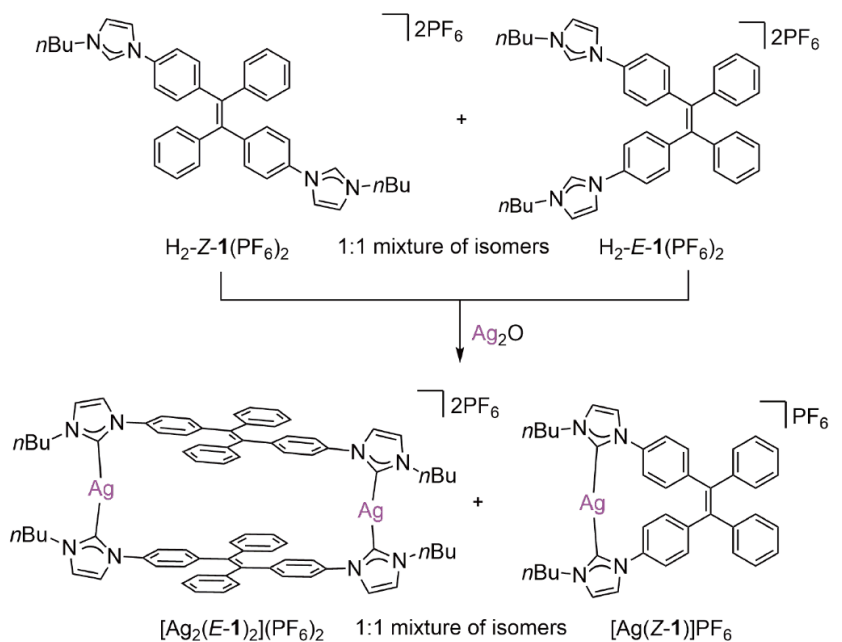

$\left[\mathrm{Ag}_{2}(E-1)_{2}\right]\left(\mathrm{PF}_{6}\right)_{2} \quad 1: 1$ mixture of isomers $\quad[\mathrm{Ag}(\mathrm{Z}-1)] \mathrm{PF}_{6}$

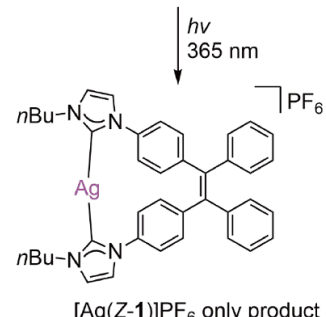

Scheme 3 Irradiation of the complex mixture $\left[\operatorname{Ag}_{2}(E-1)_{2}\right]\left(\mathrm{PF}_{6}\right)_{2} /[\mathrm{Ag}(Z-1)]-$ $\mathrm{PF}_{6}$ to give exclusively complex $[\mathrm{Ag}(Z-1)] \mathrm{PF}_{6}$ (color online).

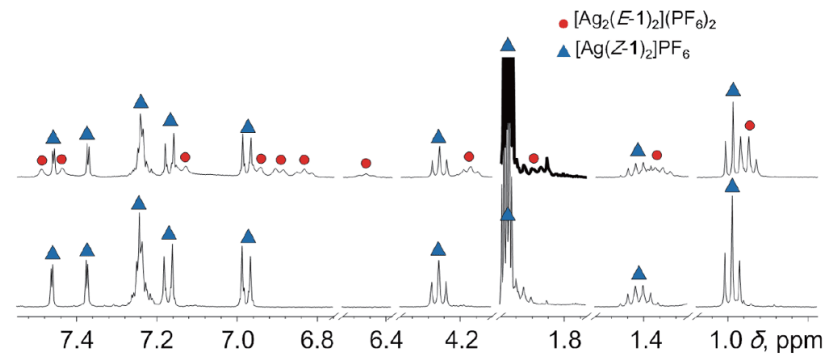

Figure $6{ }^{1} \mathrm{H}$ NMR spectrum of the complex mixture $\left[\mathrm{Ag}_{2}(E-\mathbf{1})_{2}\right]\left(\mathrm{PF}_{6}\right)_{2} /$ $\left[\mathrm{Ag}(Z-1) \mathrm{PF}_{6}\right.$ before irradiation (top) and after irradiation (bottom) (color online).
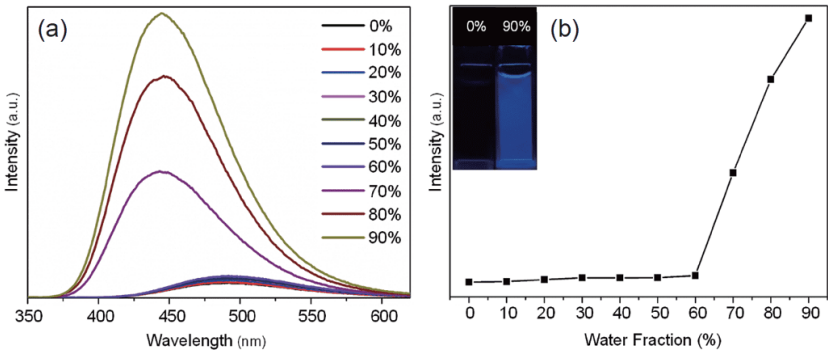

Figure 7 (a) Fluorescence emission spectra and (b) plot of maximum intensity for $\left[\mathrm{Ag}_{2}(E-1)_{2}\right]\left(\mathrm{PF}_{6}\right)_{2}$ in $\mathrm{CH}_{3} \mathrm{CN} / \mathrm{H}_{2} \mathrm{O}$ mixtures of varying $\mathrm{H}_{2} \mathrm{O}$ content $\left(\lambda_{\mathrm{ex}}=314 \mathrm{~nm}, c=10^{-5} \mathrm{M}, T=298 \mathrm{~K}\right)$. Inset: photographic image of a $10^{-5} \mathrm{M}$ solution with water contents of 0 and $90 \%$ upon excitation at $\lambda$ $=365 \mathrm{~nm}$ using a UV lamp (color online).

observed for the pure $\mathrm{CH}_{3} \mathrm{CN}$ solution (Table S9). Similarly to $\left[\mathrm{Ag}_{2}(E-\mathbf{1})_{2}\right]\left(\mathrm{PF}_{6}\right)_{2}$, complex $[\mathrm{Ag}(Z-\mathbf{1})] \mathrm{PF}_{6}$ exhibited a blue 

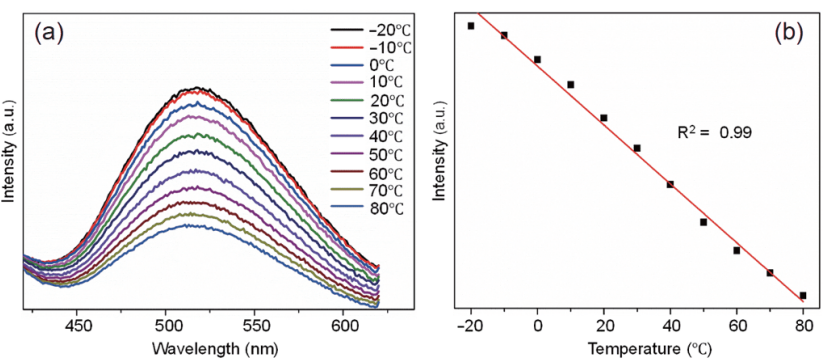

Figure 8 (a) Fluorescence spectra and (b) plot of maximum emission intensity for $[\mathrm{Ag}(Z-1)] \mathrm{PF}_{6}$ in $\mathrm{CH}_{3} \mathrm{CN}$ at different temperatures $\left(c=10^{-5} \mathrm{M}\right.$, $\lambda_{\mathrm{ex}}=314 \mathrm{~nm}$ ) (color online).

shift $(\sim 19 \mathrm{~nm})$ of the emission maximum and a significant increase in emission intensity ( $\Phi_{\mathrm{F}}$ up to $26.60 \%$ ) as the water content of the acetonitrile/water solution reached $90 \%$ (Figures S47-S50 and Table S10).

Finally, the fluorescence behavior of complex $[\operatorname{Ag}(Z-1)]-$ $\mathrm{PF}_{6}$ at different temperatures was investigated [52,53]. No obvious influence on the emission wavelength was observed by temperature dependent fluorescence spectroscopy (Figure 8a) aside from an approximately linear decrease in emission intensities with increasing temperatures (Figure $8 \mathrm{~b}$ ). The emission intensities recovered when the solutions were allowed to cool. Listings of all photophysical properties of complexes $\left[\mathrm{Ag}_{2}(E-\mathbf{1})_{2}\right]\left(\mathrm{PF}_{6}\right)_{2}$ and $[\mathrm{Ag}(Z-\mathbf{1})] \mathrm{PF}_{6}$ are presented in the Supporting Information online.

\section{Conclusions}

We have demonstrated the quantitative isomerization of $E$ - to $Z$-isomers of bisimidazolium substituted TPE by a lighttrigged structural transformation via a dinuclear silver(I) molecular rectangle featuring an $E$-di-NHC bridge to a mononuclear silver(I) complex featuring a chelating $Z$-diNHC. The $E$ - to $Z$-isomerization is not possible directly with the bisimidazolium salts without their previous transformation into di-NHC complexes. The isomerization process of the complexes has been monitored by NMR and fluorescence emission spectroscopy. Significantly different fluorescence properties of the complexes bearing the $E$ or $Z$ diNHC ligands have been observed. In addition, the complexes exhibit classical AIE characteristics. Our study provides a simple and efficient approach towards the controlled isomerization of $Z$ to $E$ disubstituted TPE derivatives through organometallic intermediates, paving the way for further studies of the EZI process in TPE derivatives.

Acknowledgements This work was supported by the National Natural Science Fund for Distinguished Young Scholars of China (22025107), the National Youth Top-notch Talent Support Program of China, and Key Science and Technology Innovation Team of Shaanxi Province (2019TD-007, 2019JLZ-02). The FM\&EM International Joint Laboratory of Northwest
University is gratefully acknowledged. FEH gratefully acknowledges financial support from the DFG (SFB 858, IRTG 2027).

Conflict of interest The authors declare no conflict of interest.

Funding note Open Access funding enabled and organized by Projekt DEAL.

Supporting information The supporting information is available online at http://chem.scichina.com and http://link.springer.com/journal/11426. The supporting materials are published as submitted, without typesetting or editing. The responsibility for scientific accuracy and content remains entirely with the authors.

Open Access This article is licensed under a Creative Commons Attribution 4.0 International License, which permits use, sharing, adaptation, distribution and reproduction in any medium or format, as long as you give appropriate credit to the original author(s) and the source, provide a link to the Creative Commons licence, and indicate if changes were made. The images or other third party material in this article are included in the article's Creative Commons licence, unless indicated otherwise in a credit line to the material. If material is not included in the article's Creative Commons licence and your intended use is not permitted by statutory regulation or exceeds the permitted use, you will need to obtain permission directly from the copyright holder. To view a copy of this licence, visit http://creativecommons.org/licenses/by/4.0/.

1 Luo J, Xie Z, Lam JWY, Cheng L, Chen H, Qiu C, Kwok HS, Zhan X, Liu Y, Zhu D, Tang BZ. Chem Commun, 2001, 1740-1741

2 Mei J, Leung NLC, Kwok RTK, Lam JWY, Tang BZ. Chem Rev, 2015, 115: 11718-11940

3 Ding D, Li K, Liu B, Tang BZ. Acc Chem Res, 2013, 46: 2441-2453

4 Hong Y, Lam JWY, Tang BZ. Chem Soc Rev, 2011, 40: 5361-5388

5 Mei J, Hong Y, Lam JWY, Qin A, Tang Y, Tang BZ. Adv Mater, 2014, 26: 5429-5479

6 Zhao GJ, Han KL, Lei YB, Dou YS. J Chem Phys, 2007, 127: 094307

7 Xiong JB, Yuan YX, Wang L, Sun JP, Qiao WG, Zhang HC, Duan M, Han H, Zhang S, Zheng YS. Org Lett, 2018, 20: 373-376

8 Kokado K, Machida T, Iwasa T, Taketsugu T, Sada K. J Phys Chem C, 2018, 122: 245-251

9 Prlj A, Došlić N, Corminboeuf C. Phys Chem Chem Phys, 2016, 18: 11606-11609

10 Yang Z, Qin W, Leung NLC, Arseneault M, Lam JWY, Liang G, Sung HHY, Williams ID, Tang BZ. J Mater Chem C, 2016, 4: 99-107

11 Liu Y, Ye X, Liu G, Lv Y, Zhang X, Chen S, Lam JWY, Kwok HS, Tao X, Tang BZ. J Mater Chem C, 2014, 2: 1004-1009

12 He L, Liu X, Liang J, Cong Y, Weng Z, Bu W. Chem Commun, 2015, 51: 7148-7151

13 Garg K, Ganapathi E, Rajakannu P, Ravikanth M. Phys Chem Chem Phys, 2015, 17: 19465-19473

14 Xie N, Liu Y, Hu R, Leung NLC, Arseneault M, Tang BZ. Isr J Chem, 2014, 54: 958-966

15 Wang Z, Cheng X, Qin A, Zhang H, Sun JZ, Tang BZ. J Phys Chem B, 2018, 122: 2165-2176

16 Le Bras L, Adamo C, Perrier A. J Phys Chem C, 2017, 121: 2560325616

17 Ghosh KR, Saha SK, Gao JP, Wang ZY. Chem Commun, 2014, 50: 716-718

18 Hurlock MJ, Kan Y, Lécrivain T, Lapka J, Nash KL, Zhang Q. Cryst Growth Des, 2018, 18: 6197-6203

19 Ye X, Liu Y, Lv Y, Liu G, Zheng X, Han Q, Jackson KA, Tao X. Angew Chem Int Ed, 2015, 54: 7976-7980

20 Xu J, Zhang C, Wang X, Jiang J, Wang F. Acta Chim Sin, 2017, 75: 473-478

21 Zhou SY, Wan HB, Zhou F, Gu PY, Xu QF, Lu JM. Chin J Polym Sci, 2019, 37: 302-326 
22 Xie Y, Li Z. Chem Asian J, 2019, 14: 2524-2541

23 Hu YB, Lam JWY, Tang BZ. Chin J Polym Sci, 2019, 37: 289-301

24 Tian W, Lin T, Chen H, Wang W. ACS Appl Mater Interfaces, 2019, 11: $6302-6314$

25 Jia J, Wen J. Tetrahedron Lett, 2020, 61: 151577

26 Lu Z, Lu S, Cheng Y, Qin Y, Yang S, Liu X, Fan W, Zheng L, Zhang H. J PhotoChem PhotoBiol A-Chem, 2020, 392: 112357

27 Chen H, Fan Y, Yu X, Semetey V, Trépout S, Li MH. ACS Nano, 2021, 15: 884-893

28 Rouillon J, Blahut J, Jean M, Albalat M, Vanthuyne N, Lesage A, Ali LMA, Hadj-Kaddour K, Onofre M, Gary-Bobo M, Micouin G, Banyasz A, Le Bahers T, Andraud C, Monnereau C. ACS Appl Mater Interfaces, 2020, 12: 55157-55168

29 Sun N, Su K, Zhou Z, Wang D, Fery A, Lissel F, Zhao X, Chen C. Macromolecules, 2020, 53: 10117-10127

30 Wang J, Mei J, Hu R, Sun JZ, Qin A, Tang BZ. J Am Chem Soc, 2012, 134: 9956-9966

31 Fang X, Zhang YM, Chang K, Liu Z, Su X, Chen H, Zhang SXA, Liu Y, Wu C. Chem Mater, 2016, 28: 6628-6636

32 Peng HQ, Zheng X, Han T, Kwok RTK, Lam JWY, Huang X, Tang BZ. J Am Chem Soc, 2017, 139: 10150-10156

33 Zhang CJ, Feng G, Xu S, Zhu Z, Lu X, Wu J, Liu B. Angew Chem Int Ed, 2016, 55: 6192-6196

34 Hu R, Lam JWY, Liu J, Sung HHY, Williams ID, Yue Z, Wong KS, Yuen MMF, Tang BZ. Polym Chem, 2012, 3: 1481-1489

$35 \mathrm{Yu}$ WH, Chen C, Hu P, Wang BQ, Redshaw C, Zhao KQ. RSC Adv, 2013, 3: 14099-14105

36 Tseng NW, Liu J, Ng JCY, Lam JWY, Sung HHY, Williams ID, Tang BZ. Chem Sci, 2012, 3: 493-497

37 Rit A, Pape T, Hahn FE. J Am Chem Soc, 2010, 132: 4572-4573
39 Segarra C, Guisado-Barrios G, Hahn FE, Peris E. Organometallics, 2014, 33: 5077-5080

40 (a) Sinha N, Hahn FE. Acc Chem Res, 2017, 50: 2167-2184; (b) Gan MM, Liu JQ, Zhang L, Wang YY, Hahn FE, Han YF. Chem Rev, 2018, 118: 9587-9641

41 Sun LY, Sinha N, Yan T, Wang YS, Tan TTY, Yu L, Han YF, Hahn FE. Angew Chem Int Ed, 2018, 57: 5161-5165

42 Martínez-Agramunt V, Eder T, Darmandeh H, Guisado-Barrios G, Peris E. Angew Chem Int Ed, 2019, 58: 5682-5686

43 Ibáñez S, Peris E. Angew Chem Int Ed, 2019, 58: 6693-6697

44 Ibáñez S, Poyatos M, Peris E. Acc Chem Res, 2020, 53: 1401-1413

45 Sinha N, Tan TTY, Peris E, Hahn FE. Angew Chem Int Ed, 2017, 56: 7393-7397

46 Wang YS, Feng T, Wang YY, Hahn FE, Han YF. Angew Chem Int Ed, 2018, 57: 15767-15771

47 Li Y, Yang T, Li N, Bai S, Li X, Ma LL, Wang K, Zhang Y, Han YF. CCS Chem, 2021, 3: 957-968

48 Li Y, Yu JG, Ma LL, Li M, An YY, Han YF. Sci China Chem, 2021, 64: 701-718

49 Sinha N, Stegemann L, Tan TTY, Doltsinis NL, Strassert CA, Hahn FE. Angew Chem Int Ed, 2017, 56: 2785-2789

50 Li Y, An YY, Fan JZ, Liu XX, Li X, Hahn FE, Wang YY, Han YF. Angew Chem Int Ed, 2020, 59: 10073-10080

51 Haldar R, Diring S, Samanta PK, Muth M, Clancy W, Mazel A, Schlabach S, Kirschhöfer F, Brenner-Weiß G, Pati SK, Odobel F, Wöll C. Angew Chem Int Ed, 2018, 57: 13662-13665

52 Zhang Z, Zhao Z, Wu L, Lu S, Ling S, Li G, Xu L, Ma L, Hou Y, Wang X, Li X, He G, Wang K, Zou B, Zhang M. J Am Chem Soc, 2020, 142: 2592-2600

53 Yan X, Cook TR, Wang P, Huang F, Stang PJ. Nat Chem, 2015, 7: $342-348$ 